\title{
Expected Success Factors for Public Sector Projects in Nigeria: A Stakeholder Analysis
}

DOI 10.5592/otmcj.2013.2.4 Research paper

\author{
Martin Oloruntobi Dada \\ Department of Building, \\ Faculty of Environmental Sciences \\ University of Lagos, Akoka, Yaba, Lagos, Nigeria \\ mdada@unilag.edu.ng
}

\section{Keywords}

Public Project Implementation, Clients, Contractor Organizations, Stakeholder Management, Nigeria
ANALYSING AND MANAGING STAKEHOLDERS' VIEWS HAVE BEEN RECOGNIZED AS NECESSARY FOR THE SUCCESS OF PROJECTS OR PROGRAMS. This research set out to investigate the expectations of client and contracting organizations in the Nigerian construction industry on their priorities for public project implementation. An opinion survey of client and contracting organizations in the Federal Capital Territory and some selected states of Nigeria was done. A set of 151 questionnaires was administered through the use of purposive and snowballing techniques on clients and contracting organizations. 67 completed questionnaires were returned. The data collected was subjected to both descriptive and inferential statistical analyses. The results suggest that there are no significant differences, between client and contracting organizations, in their assessment of the six identified priorities in public sector project implementation. The study recommends that the homogeneity of perceptions by the two organizations can be a platform for intervention efforts for improvements in public sector project delivery. 


\section{INTRODUCTION}

The way public projects are executed is of paramount interest to the citizens of any nation. As a matter of fact, the way public projects are procured has the possibility of determining the popularity of a government and the future direction of the nation state. This is because public infrastructure projects consume government revenue, provide infrastructure, alter and affect the environment and thus contribute to, or detract from the enlightened self-interest of nations (Dada, 2007). Petersen and Murphree (2004) assert that the public sector has both fiscal and moral responsibility to the citizenry. Public projects are executed within the larger context of the construction industry. Some developing countries have attempted to nationalize their construction sector while some have set goals for linkages of their construction industry to their overall national developmental agenda (Wells 1986; Ogunlana, 2010). Ogunlana (2010) asserted that while many Asian construction companies are over-committed in China, India and the Middle East with construction projects, Nigeria's construction sector has not made or been positioned to make similar contributions. One of the indicative parameters of Nigeria's Vision 20:20 is 'adequate infrastructure services that support the full mobilization of all economic sectors' (Ogunlana 2010 :8). Nigeria has a broad vision of using infrastructure to drive other sectors of the economy (Concept, 2007). The Nigerian Federal Government introduced the due process which culminated in the enactment of the Public Procurement Act in 2007. The BMPIU (2005) reported that a diagnostic study conducted into the state of Federal Government public procurement revealed that Nigeria may have lost several billions of naira partly due to inflation of contract costs, lack of transparency and competence based competition as criteria for the award of public contracts. This development raises questions on the implementation of public projects in Nigeria about whether there are ingredients of integration, in project implementation, of specific deliverables to national goals. Since infrastructure projects, whether public or private, are part of the outputs of the construction industry, the existence and/or use of goals and parameters with which to execute and judge public projects in Nigeria by stakeholders remains debatable. The issue for investigation in this research is thus: in the realization and execution of public projects, how do some selected stakeholders -clients and contractors-prioritise their goals and expectations in project implementation? The rationale for this investigation is the important place that stakeholder management has in the ownership, implementation and success of projects and programmes (Yuan et al., 2010; Forrer et al., 2010; Li et al., 2012).

\section{Public projects: priorities and stakeholder management}

Building and civil engineering construction (in which public projects are included) in Nigeria was reported to have contributed as much as $3.4 \%$ to the gross domestic product of that nation (Federal Office of Statistics, 1998). Nigeria still has a large mass of infrastructure to provide for her citizens. Some of the infrastructure are provided for or enabled by the public sector depending on procurement form and arrangement. Whichever procurement method is used, underlying expectations exist.

Even though project priorities may differ from one client to the other, priorities for project implementation nonetheless exist (Greenberg, 1993; Peters and Hommers, 1997). Some nations have goals in the execution of their public projects. Public projects are a common trust and just as any other projects there should be parameters to measure their success. Literature position indicates some goals or strategies of some countries to integrate developmental agenda into their public project implementation. Some goals or measures of success on a public project include but are not limited to (Wells, 1986; Masterman, 1992; Anyaegbunam, 2002; PPA, 2007; Park et al., 2012):(a). Project implementation at least or budgeted cost; (b) Project implementation at least or budgeted time; (Project implementation to meet agreed or expected quality considerations; (d) Transparency and accountability; (e) Project implementation to promote technology transfer to nationals; (f) Project implementation to generate employment opportunities for nationals; (g) Project implementation in such a way as not to affect health and safety and the environment or ecosystem, or project implementation using the principle of sustainability; and (h) Poverty alleviation and other socio economic goals

The first three goals or objectives are regarded as the traditional micromeasures of success or project performance. Pinto and Slevin (1988) equally developed what they termed surrogate measures to determine project success, however some of these measures are limited to the project or are at the project level and are not intertwined with any political or national vision. For some public projects, profitability may not be a top requirement. Park et al. (2012) explained that in some international development projects, which are examples of public projects, the target or driver of the project may not be profitability but poverty reduction. Forrer et al. (2010) provided an analytical framework in which the use of public-private-partnership (PPP) for procurement of goods and services can meet public sector requirements of efficiency, effectiveness and equity. Forrer et al. (2010) also added accountability as a requirement in modeling the procurement of public projects.

The proneness to corruption being 
reported or assessed by such organizations as Transparency International and other multilateral institutions is not just limited to the procurement of services but also the procurement of tangible infrastructure projects (Transparency International, 2010). Thus any attempt to improve the welfare of the citizens of a nation will involve efforts directed at executing their public projects efficiently and in line with their national goals and ethos. Logically, some of these measures can be regarded as critical success factors (CSFs) in public project implementation. CSFs can be process or project related and they can be at project or organizational or at both levels concurrently. The measures of the success or performance of public projects may then be local measures to the project or measures that go beyond the immediate. Knowing and keeping to CSFs will improve organizational performance (Russell, 2008).

On the project level, CSFs are factors that enhance project performance. An understanding of CSFs may assist business executives in improving their processes so as to reduce the cost of project failure (Russell, 2008). The concept of CSFs has been applied as a management measure in a number of sectors. Thus, there have been attempts to apply this same concept to construction management. The concept of the CSFs cuts across different fields of human endeavour (Yu et al., 2006; Omran et al., 2010; Ansarinejad et al., 2011) where process improvement is desired. CSFs on projects have attracted the attention of researchers and practitioners. How are Nigeria's public projects assessed with respect to project priorities or deliverables or goals in project implementation?

Government especially in participative democracies is about people (Ogunlana, 2006). Hence all activities of government even in project execution should be directed to protecting the common good of the citizens. This study thus investigates the perceptions of a critical sector among immediate project participants -client organizations and contracting organizations- regarding public project implementation. In the first instance, these two sets of organisations have experience of construction procurement. It is expected that the views of these organizations can shape the formulation and success of implementation of government public project procurement policies. Stakeholder integration and management, which have been identified as necessary to the success of projects, have been lacking in implementation of some past public projects (The Guardian, 2002). Yet, the necessity of considering the perspective of different stakeholders in performance measurement of projects has been cannot be over-emphasised (El-Gohary, 2006; Yang et al., 2009; Yuan et al, 2010; Forrer et al., 2010; Li et al., 2012). It is in this context that the views and perceptions of client and contracting organizations on what they expected should be priorities in project implementation are located. Perceptions, whether right or wrong, have the possibility of influencing behavior and determining customer patronage, choices and courses of action (Smith \& Nagle, 1995; Dada \& Oladokun, 2008). This research thus investigates whether significant differences exist in the importance rating of those issues by both construction industry clients and consultants. The study should thus contribute to the body of knowledge on expectations of two of the key participant organisations in project delivery.

\section{Research methods}

This research was conducted through the examination of relevant literature followed by field investigation. The researcher used the three traditional micro measures of time, cost and quality and additional measures encapsulated from interviews, experience and intent of the Federal Government of Nigeria on some of her goals for public projects (Concept: 2007). The population for the research consisted of construction industry client and contracting organisations. The client organizations were either from the public or private sector. The public sector clients included ministries, departments or agencies at either the federal, state or local government levels. The contracting organizations were contractors in the built environment. A set of 151 questionnaires were administered through purposive and snowballing techniques on the construction industry clients and contracting organizations located in at least thirteen states of Nigeria. The questionnaires were administered through purposive and snowballing techniques. The use of these non-probabilistic methods was due to a lack of reliable and comprehensive database of the respondent organizations. The use of such methods has found application in construction or project management research, as it has been opined that in some instances such methods are the only practical way of getting data on a subject matter (Kidder, 1981; Li et al.., 2005). $94 \%$ of the respondent organisations that identified their locations were from thirteen states of the federation and Abuja, the federal capital territory. The remaining $6 \%$ did not indicate their locations. Construction industry professionals in the respective organizations supplied the needed information on behalf of the organizations. The professionals were any of the following: architects, builders, engineers, town-planners, estate surveyors, quantity surveyors and land surveyors.

The questionnaire sought to know the professional affiliation of the respondents that were filling out the questionnaire on behalf of the respective organizations. The questionnaire also sought to know the head office locations of the organizations, their 


\begin{tabular}{|c|c|c|c|c|c|c|}
\hline Questionnaire & $\begin{array}{c}\text { Number from } \\
\text { client org. }\end{array}$ & $\begin{array}{c}\text { \% from client } \\
\text { org. }\end{array}$ & $\begin{array}{c}\text { Number from } \\
\text { contractor org. }\end{array}$ & $\begin{array}{c}\text { \% from } \\
\text { contractor org. }\end{array}$ & $\begin{array}{c}\text { Total number } \\
\text { from both org. }\end{array}$ & $\begin{array}{c}\% \text { of total } \\
\text { number from } \\
\text { both org. }\end{array}$ \\
\hline Received & 32 & 49 & 35 & 44 & 67 & 43 \\
\hline Not received & 39 & 51 & 45 & 56 & 84 & 57 \\
\hline Total & 71 & 100 & 80 & 100 & 151 & 100 \\
\hline
\end{tabular}

Org. = organisation

Table 1. Response rate to the survey instrument

years of experience, the experience of their organization in construction commissioning, The questionnaire further asked them to rank in the order of importance their expected issues of emphasis in public sector project implementation. Rank ' 1 ' was the highest while ' 6 ' was the least among six issues identified. The issues were: project completion at the least/budgeted cost, project completion at the least/ budgeted time, project completion to agreed quality expectations, project completion enhancing transparency and accountability to the electorate, project implementation enhancing technology transfer to Nigerians and project implementation for prestige effect or status symbol. Respondents were however given the opportunity to incorporate additional issues to the list and were then required to rank accordingly. The level of significance for statistical testing was set at $5 \%$.

\section{Analysis, results and discussions}

Lagos State houses the head offices of the highest number of the organizations (with a frequency of 44 which translated to $66 \%$ ) for the opinion survey instrument. Ondo, Oyo, Kogi, Anambra state each houses 1 (1.5\%). Enugu state houses 6 ( $9 \%$ ) respondent organizations. Rivers state and Abuja house $3(4.5)$ and $2(3 \%)$ respectively of the projects. In 3 (4.5) of responses, head office locations showing states were not indicated. The field of operations of construction organizations can be dispersed and different from head office locations because of the nature of construction works. Additionally, Lagos state has the highest proportion of respondent organizations because Lagos remains the economic and commercial nerve center of Nigeria.

Descriptive data analysis and results Table 1 shows the response rate to the questionnaire.

From Table 1, it is observed that the response rate by the client organizations to the questionnaire was $49 \%$ and that of the contractors' questionnaire was $38 \%$. The aggregated response rate was $43 \%$. Table 2 indicates the professional affiliations of respondents

The second, fourth and sixth columns of Table 2 indicate the number of respondents while the third, fifth and seventh columns respectively

\begin{tabular}{|c|c|c|c|c|c|c|}
\hline Professionals & NCL & PCL & NCT & PCT & NTOT & PTOT \\
\hline Architect & 3 & 9.40 & 0 & & 3 & 4.47 \\
\hline Builder & 12 & 37.50 & 12 & $34 \cdot 3$ & 24 & 35.83 \\
\hline Civil/structural engineers & 6 & 18.80 & 9 & $25 \cdot 7$ & 15 & 22.38 \\
\hline Mechanical Engineers & 2 & 6.30 & 2 & 5.7 & 4 & 5.97 \\
\hline Estate surveyors & 3 & 9.40 & 2 & 5.7 & 5 & 7.46 \\
\hline Quantity surveyors & 4 & 12.50 & 5 & $14 \cdot 3$ & 9 & 13.44 \\
\hline Dual or more professions & 2 & 6.30 & 4 & 11.4 & 6 & 8.96 \\
\hline Profession not indicated & & & 1 & 2.85 & 1 & 1.49 \\
\hline Total & 32 & 100 & 35 & 100 & 67 & 100 \\
\hline
\end{tabular}

$\mathrm{NCL}=$ Number of client organizations; $\mathrm{PCL}=\%$ of client organizations; $\mathrm{NCT}=$ Number of contractor organizations; $\mathrm{PCS}=\%$ of contractor organizations; NTOT $=$ Total number in both organizations; PTOT $=\%$ of total number

Table 2. Professional affiliations of respondents. 


\begin{tabular}{|c|c|c|c|c|c|c|}
\hline Qualification & NCL & PCL & NCT & PCT & NTOT & PTOT \\
\hline Masters & 6 & 18.70 & 9 & 25.70 & 15 & 22.40 \\
\hline Bachelors & 18 & 56.30 & 14 & 40.00 & 32 & 47.80 \\
\hline HND & 8 & 25.00 & 8 & 22.90 & 16 & 23.80 \\
\hline OND & - & - & 2 & 5.70 & 2 & 3.00 \\
\hline Not indicated & - & - & 2 & 5.70 & 2 & 3.00 \\
\hline Total & 32 & 100.00 & 33 & 100.00 & 67 & 100.00 \\
\hline
\end{tabular}

$\mathrm{NCL}=$ Number of client organizations; $\mathrm{PCL}=\%$ of client organizations; $\mathrm{NCS}=$ Number of consultant organizations; PCS $=\%$ of consultant organizations; NTOT $=$ Total number in both organizations; PTOT $=\%$ of total number; HND = Higher National Diploma.

\section{Table 3. Highest academic qualifications of respondents}

indicate the associated percentages with respect to the total for that group. The table indicates that builders dominated the representatives of respondents that completed the supplied information for contractor organizations. For client organizations, civil/ structural engineers dominated. It is worth noting that in Nigeria, builders refer to professionals that are trained and licensed for building production management. They are different from contractors who are regarded as business persons. Builders in Nigeria are licensed to practice the building profession by the Council of Registered Builders of Nigeria. It is in this context that the word 'builder' is used in this research paper.

Table 3 shows the highest academic qualifications of construction industry professionals who completed the questionnaire on behalf of their organizations.

Table 3 indicates that bachelors degree holders - 14 (40.00\%) - dominated the respondents who were representatives in the contractor group,. Equally, bachelor's degree holders dominated the client group. $15(22.40 \%)$ of individuals who stood for their respondent organisations had masters degree while $32(47.80 \%)$ had the bachelors degree. 16 (23.80\%) had the higher national diploma qualification while 2 (3.08\%) did not indicate their highest educational qualification. On the whole, bachelor's degree holders dominated respondents' representatives in the aggregated groupings. The insight that can be gained from the table is that not less than $96.10 \%$ of respondents have at least a degree or equivalent qualification. It can be argued that the understanding of the respondents on the subject matter could be better guaranteed.

Inferential analysis and results In an attempt to examine if differences exist in the assessments of the two groups, an inferential statistical investigation was made. In the process, the following null and alternative hypotheses were postulated:

Null Hypothesis $\left(\mathrm{H}_{\mathrm{o}}\right)$ : There is no significant difference between client and contracting organizations in their assessment of expected deliverables or priorities in public project implementation

Alternative Hypothesis $\left(\mathrm{H}_{1}\right)$ : There is significant difference between client and contracting organizations in their assessment of expected deliverables or priorities in public project implementation

The testing of these hypotheses was done through the use of the Mann Whitney-U analysis. Each of the six identified issues was subjected to Mann-Whitney-U analysis to arrive at a categorical statement regarding differences or otherwise between the two stakeholder groups - client and contracting organizations. The Mann Whitney- $U$ analysis is a non-parametric equivalent of the students-t test

\begin{tabular}{|c|c|c|c|c|c|}
\hline Issue for assessment & MRCT & MRCL & U-value & P-value & Decision \\
\hline Project completion at expected time & 32.39 & $35 \cdot 77$ & 616.50 & 0.442 & Accept $\mathrm{H}_{\mathrm{o}}$ \\
\hline Project completion at expected cost & 33.20 & 34.88 & 588.00 & 0.701 & Accept $\mathrm{H}_{\text {o }}$ \\
\hline $\begin{array}{l}\text { Project completion meeting or exceeding expected or } \\
\text { agreed quality expectations }\end{array}$ & 33.34 & $34 \cdot 72$ & 583.00 & 0.699 & Accept $\mathrm{H}_{\mathrm{o}}$ \\
\hline $\begin{array}{l}\text { Project completion meeting transparency or } \\
\text { accountability considerations }\end{array}$ & 33.17 & 34.91 & 589.00 & 0.699 & Accept $\mathrm{H}_{\mathrm{o}}$ \\
\hline Project completion for prestige or status symbol & 36.93 & 30.80 & $457 \cdot 50$ & 0.164 & Accept $\mathrm{H}_{\mathrm{o}}$ \\
\hline Project completion providing technology transfer & 34.04 & 33.95 & 558.500 & 0.985 & Accept $\mathrm{H}_{\mathrm{o}}$ \\
\hline
\end{tabular}

$\mathrm{MRCT}=$ Mean rank for contractor group; $\mathrm{MRCL}=$ Mean rank for client group

Table 4. Mann Whitney-U analysis of expected issues of emphasis by client and contracting organisations 
(Levin, 1987; Kinnear and Gray, 2000; Gupta, 2001). The analysis is suitable for use in this research. Two groups are being compared here and the scales used are ordinal. Table 4 shows the edited output of the results.

Table 4 shows the mean ranks for the groups the U-values, and the probability values for the issues used for Mann Whitney $-U$ analysis. From the descriptive analysis perspective, the lower the mean rank value for any of the respondent group, the higher is the rank assigned to that issue by that group in project implementation. From the inferential analysis perspective, the table indicates all the U-values which imply that the results are not significant. (The implication is to accept the null hypothesis for each of the issues used for assessment). Alternatively, the probability values ( $p$-values) were examined for decision making according to Asika (1991) and Kinnear and Gray (2000). In Table 4 all the p-values are less than the set level of statistical significance ( $5 \%)$. The decision is thus to accept the null hypothesis. It is thus concluded that there are no significant differences between client and contracting organisations in the rankings or assessments of the respective expected issues of emphasis in public project implementation.

\section{Discussion}

The inferential analysis indicates that the two groups -client and contracting organizations- agree on the issues. There is no significant difference between client and contracting organizations with respect to their assessment of the following issues in project implementation: project completion at expected time, project completion at expected cost, project completion meeting or exceeding expected or agreed quality expectations, project completion meeting transparency or accountability considerations, project completion for prestige or status symbol, project completion providing technology transfer to Nigerians. The assessment of the two groups were not statistically divergent but homogenous. This result warrants closer examination for underlying phenomena. Clients and contractors are assumed to be different entities that may have different commercial goals and perspectives. Yet they assess goals for public project in the same way. This could indicate that the two groups have either understood themselves so well to have a congruence of views. It could also mean that irrespective of their organizational affiliations, the two groups are united in their goals of expectation for public projects. It could also be an indicator of their nationalistic fervor. It may therefore mean that irrespective of organizational and commercial philosophy, the two groups seem to possess common perceptions on priorities for public projects. This development further raises a question: what is the relationship between organizational or commercial charters or philosophy of stakeholder organizations and their nationalistic or nation-building disposition? Additionally, do nationalities of stakeholder groups affect their expectations in the implementation of public projects in Nigeria or elsewhere? These are questions that may warrant investigation in future researches.

The outcome of this research is similar to the one conducted by Dada (2007) to examine the perceptions of consultants and clients' organisations on their expectations for public project implementation. Even though the present study focuses on client and consulting organizations' views on public projects, it is interesting that as in the results of Dada (2007), there are no significant differences in expectations of the two respondent groups on public projects. The policy implication of this research finding is that since the views of the two groups -clients and contractor organizations-are homogenous, intervention programs for the execution of public projects when hinged on the above areas of emphasis, should logically meet with little or no resistance. It should also be possible to evolve participative project implementation strategies to avoid the reasons adduced to have contributed to the failure of many public projects (The Guardian, 2002). The rankings or the issues are also possible measures on which the performance of public projects executed in the past can be gauged. The measures can be used in analyzing the potential worth, contribution and utility of planned future projects. The author acknowledges a possible limitation to the use of the results of this work in the area of generalisability due to the sampling method used. The results of the work are however useful and indicative and can lend direction to future research.

\section{Conclusions and \\ recommendations}

The study set out to assess expected priorities attached to the implementation of public sector projects in Nigeria from the perspectives of both client and contracting organizations. The study sought to determine whether differences exist between the two organizations on the expected priorities. The issues used for assessment were: project completion at expected time, project completion at expected cost, project completion meeting or exceeding expected or agreed quality expectations, project completion meeting transparency or accountability considerations, project completion for prestige or status symbol, project completion providing technology transfer to Nigerians. The results indicate that there were no statistical significant differences in the assessment by the two groups. This implies that there are no significant differences between client and contracting organizations with respect to their assessment of the identified priorities in project implementation. The results further throw up some observations that despite 
the fact that the two organizations are different commercial entities and sometimes with possibly different visions, yet they do not exhibit differences on expected priorities in the execution of public projects. While this development may be an indication of seeing from the same perspective, it could also be a pointer to nationalistic fervor generating or predisposing to the assessments. It is recommended that all stakeholders in public sector project implementation should take advantage of homogeneity of expectations in evolving and implementing strategies for improvement and innovation in public sector project procurement. A similar study can be conducted in other countries to assess stakeholder's expectations all in an attempt to promote stakeholder engagement. The stakeholders used in future studies can also be expanded beyond the present scope of client and contracting organizations. The role of nationality and nationalistic fervor in assessment of expectations or prioritizations on public projects by stakeholder groups may also be examined.

\section{References}

Anyaegbunam, J.C (2002), "The Nigerian professionals and multinational construction companies --Which way forward?", Paper presented at the National Seminar on Planning and Execution of Capital Projects in an Emerging Democracy organized by The Nigerian Institute of Building held in March, 2002 at Abuja.

Ansarinejad, A., Amalnick, M., Ghadamyan A.S. and Hatami-Shirkonchi, L. (2011), "Evaluating the critical success factors in ERP implementation using fuzzy AHP approach”. International Journal of Academic Research, Vol. 3 No. 1, Part I, pp. 65-80.

Asika, N. (1991), Research methodology in the behavioral sciences, Longman, Lagos.

Budget Monitoring and Price Intelligence Unit (2005), The ABC of the contract due process policy: A manual on public procurement reform programme in Nigeria, State House, Abuja.

Chan, A.P.C., Lam, P.T.I., Chan, D.W.M., Cheung, E., and Yongjian, K. (2010), "Critical success factors for PPPs in infrastructure developments: Chinese perspectives", Construction Management and Economics, Vol. 136 No. 5, pp. 484-494.

Concept (2007), The concept paper for Nigeria's Vision 20:20. Available at http://www. nv2020.org/

Dada, M.O. (2007), "Priorities in Nigerian public project implementation: Expectations from consultants and contractors", Construction Research Journal, Vol.1 No. 1, pp. 10-14.

Dada, M.O., and Oladokun, G. (2008), “Critical Success factors in public-private- partnership projects in Nigeria: A perceptual survey", in Karter, C., Ogunlana, S.O., and Kaka, A. (Eds). Transformation through construction: Joint 2008 CIB Wo65/055 Symposium proceedings. Herriot Watt University, Edinburgh, pp. 1-10.

El-Gohary, N.M., Osman, H., and El-Diraby, T.E. (2006), "Stakeholder management for public private partnerships”, International Journal of Project Management, Vol. 24, pp. 595-604.

Federal Office of Statistics (1998), Nigerian National Accounts, Federal Government Press, Lagos.

Forrer, J., Kee. J.E., and Newcomer, K.E. (2010), "PPPs and the public accountability question”, Public Administration Review, May/June, pp. 475-484.
Greenberg, T. (1993), “Project types in building and construction", International Journal of project Management, Vol.11No. 2, pp. $68-72$.

Gupta, S.P. (2001), Statistical methods $13^{\text {th }}$ edition Sultan Chand and Sons, New Delhi.

Hardcastle, C., Edwards, P.J., Akintoye, A. and Li, B. (2005), "Critical success factors for PPP/ PFI projects in the UK construction industry: A factor analysis approach", Construction Management and Economics, Vol. 23 No. 5,pp. 459-471.

Kidder, L.H. (1981), Seltiz, Wrightsman and Cook's Research Methods in Social Relations, Holt, Rinehart and Winston, Japan.

Kinnear, P. R., and Gray, C. D. (2000), SPSS for windows made simple: Release 10 , Psychology Press Ltd., UK.

Li, B., Akintoye, A., Edwards, P.J., and Hardcastle, C. (2005), "Critical success factors for PPP/ PFI projects in the UK construction industry", Construction Management and Economics, Vol. 23, pp. $459-471$.

Li, T.H.Y. Ng, S.T. and Skitmore, M. (2012), "Conflicts or consensus: an investigation of stakeholder concerns during the participation process of major infrastructure and construction projects in Hong Kong", Habitat International, Vol. 36, pp. 333-342.

Masterman, J. W. E. (1992), Introduction to procurement systems, E \& FN Spon Ltd., London.

Ogunlana, S.O. (2006), “Sustainable buildings: Where should we be heading?" In Okewole, I.A., Daramola, S.A., Ajayi, C.A., Ogunba, O.A., and Odusami K.T. The built environment: Innovation policy and sustainable development, Covenant University, Sango-Ota, pp. $x x v-x x x$.

Ogunlana, S.O. (2010), "Sustaining the 20:2020 vision through construction: A stakeholder participatory approach", Distinguished lecture Series of the School of Postgraduate Studies, University of Lagos, delivered on February 10, 2010.

Omran, A., Omran, A., and Kadir, A. H.P. (2010), "Critical success factors influencing safety program performance in Malaysian construction projects: Case studies", Journal of academic research in Economics, Vol. 2 No. 1, pp. 124-134.

Peters, L. A., and Hommers, J. L. (1997), “It's not time, cost, or quality that ensure project success: Learn project fundamentals and core processes, which are keys to project success", Paper presented at Project 
Petersen D.R., and Murphree, E. L. (2004), “The impact of owner representative in a designbuild construction environment", Project Management Journal, Vol. 3 No. 3, pp. 27-38.

Pinto, J.K. and Slevin, D.P. (1988), “Project success: Definition and measurement techniques", Project Management Journal, Vol.19 No. 1, pp. 67-71.

Public Procurement Act (PPA) (2007), Federal Government Press, Abuja.

Russell, R.K. (2008), “Critical success factors for the fuzzy front end of innovation in the medical device industry", Engineering Management Journal, Vol. 20 No. 3, pp. 36-43.

Smith, G. E., and Nagle, T.T. (1995), "Frames of reference and buyers' perception of price and value”, California Management Review, Vol. 38 No. 1 , pp. $98-116$.

The Guardian. (2002), “Failed contracts panel indicts elites for Nigeria's woes", The Guardian, Wednesday November 6, p. 3.

Transparency International (2010), Corruption perceptions index ..and how corruption affects you, Http// www.transparency.org accessed April 7, 2010.

Weaver, R .L. (1981), Understanding interpersonal communication, Scott Freeman and Co., US.

Wells, J. (1986), The construction industry in developing countries: Alternative strategies for development, Croom Helm Ltd., London.

Yang, J., Shen, G.Q., Ho, M., Drew, D.S. and Chan, A.P. C. (2009), "Exploring critical success factors for stakeholder management of construction projects", Journal of Civil Engineering, Vol. 15 No. 4, pp. 337-378.

Yu, A.T.W., Shen, Q., Kelly, J., and Hunter, K. (2006), "Investigation of critical success factors in construction project briefing by way of content analysis", Journal of Construction Engineering and Management, Vol. 132 No. 11, pp. 1178- 1186.

Yuan, J., Skibniewski, M .J., Li, Q., and Zeng, L. (2010), "Performance objective selection model in public-private-partnership projects based on the perspective of stakeholders", Journal of Management in Engineering, Vol. 26 No. 2, pp. 89-104. 